\title{
Robles in Lagunas de Epulauquen, Argentina: previous and recent evidence of their distinctive character
}

María M Azpilicueta ${ }^{1 *}$, Mario J Pastorino 1,2, Javier Puntieri2, ${ }^{2,3}$, Fernando Barbero ${ }^{1,2}$, Alejandro Martinez-Meier ${ }^{1}$, Paula Marchelli ${ }^{1,2}$ and Leonardo A Gallo ${ }^{1}$

\begin{abstract}
The northernmost 'robles' of Argentina, located in Lagunas de Epulauquen (northwest Patagonia), are considered a population of Nothofagus obliqua, even though they differ in some respects from individuals of other populations of the species. In order to analyse a possible genetic basis of their distinctive character, we revised previous information and added new evidence based on biochemical (isozyme) and molecular (chloroplast DNA and nuclear microsatellite) markers, as well as quantitative trait variation (seed traits, leaf morphology, plant architecture and field performance). The comparison of Lagunas de Epulauquen specimens with specimens from other areas in Argentina demonstrated their genetic distinction. Glacial history, in conjunction with hybridisation processes, provides support for the main hypothesis to explain these results. Future research lines are proposed, aimed at identifying the taxonomic status of the Lagunas de Epulauquen population. The conservation value of these forests is highlighted.
\end{abstract}

Keywords: Nothofagus obliqua; Taxonomy; Patagonia; Glacial history; Interspecific hybridisation

\section{Resumen}

Los robles más septentrionales de la Argentina, ubicados en Lagunas de Epulauquen (noroeste de Patagonia) son considerados una población de la especie Nothofagus obliqua, pero presentan características diferenciales respecto al resto de las poblaciones argentinas de esa especie. El presente trabajo reúne información generada previamente y otra original que demuestra el carácter genéticamente distintivo de esa población. Se presentan los resultados logrados a través de análisis genéticos con marcadores bioquímicos (isoenzimas) y moleculares (de ADN de cloroplasto y marcadores de microsatélites nucleares), con caracteres cuantitativos seminales, de morfología foliar, de arquitectura de las plantas y de aptitud a campo. La historia glacial de la región, en conjunción con procesos de hibridación pasados, se postula como la causa de esta diferenciación. Se propone la realización de nuevas líneas de investigación que permitan confirmar o re-definir el estatus taxonómico de los árboles de esta población. Adicionalmente se presenta una breve consideración sobre el valor de conservación de los bosques en Lagunas de Epulauquen, en relación a los resultados aquí presentados.

Palabras clave: Nothofagus obliqua; Taxonomía; Patagonia; Historia glacial; Hibridación interespecífica

\footnotetext{
* Correspondence: azpilicueta.maria@inta.gob.ar

'INTA (Instituto Nacional de Tecnología Agropecuaria), EEA Bariloche,

Modesta Victoria 4450, 8400 Bariloche, Argentina

Full list of author information is available at the end of the article
}

\section{它}

(C) 2014 Azpilicueta et al.; licensee Springer. This is an Open Access article distributed under the terms of the Creative Commons Attribution License (http://creativecommons.org/licenses/by/4.0), which permits unrestricted use, distribution, and reproduction in any medium, provided the original work is properly credited. 


\section{Review}

\section{Nothofagus obliqua characteristics}

Nothofagus obliqua (Mirb.) Oerst. (Nothofagaceae, Hill and Jordan 1993), known as 'roble', 'pellín', 'roble pellín' or 'hualle', is a tree species endemic to South American temperate forests. It belongs to the Lophozonia sub-genus [recently upgraded to genus in the classification by Heenan and Smissen (2013)] along with other six species (Hill and Read 1991; Martin and Dowd 1993; Heenan and Smissen 2013), three of which are also South American: Nothofagus alpina (= N. nervosa) (Poepp. \& Endl.) Oerst., Nothofagus glauca (Phil.) Krasser (Veblen et al. 1996) and Nothofagus macrocarpa (A. DC.) F. M. Vázquez and R. Rodr. (Vázquez and Rodríguez 1999).

$N$. obliqua is a wind-pollinated, outcrossing, anemochorous and deciduous forest tree occupying an extensive area of 1.2 million hectares in Chile (Veblen et al. 1996; Araya and Oyarzún 2000). It has a narrow distribution of 33,859 ha in Argentina, from $36^{\circ} 49^{\prime} \mathrm{S}$ to $40^{\circ}$ 11' S (Sabatier et al. 2011) along five lake basins (Lácar, Quillén, Norquinco, Moquehue and Lagunas de Epulauquen) and a river margin (Aluminé river; Gallo et al. 2000; Sabatier et al. 2011; Figure 1). The distribution pattern of these forests has been markedly modelled by glacial processes that affected northern Patagonia. Palynological and palaeo-climatic studies described a non-continuous ice cap at these latitudes (Rabassa and Clapperton 1990). Accordingly, many species could have survived in multiple glacial refugia (Markgraf et al. 1995; Veit and Garleff 1995) and gone on to recolonise the area in post-glacial times. Genetic studies in N. obliqua forests (Azpilicueta et al. 2009) and other South American temperate tree species (e.g. Marchelli et al. 1998; Premoli et al. 2000; Bekessy et al. 2002; Pastorino and Gallo 2002; Allnut et al. 2003; Azpilicueta et al. 2009; Marchelli et al. 2010) give support to this multiple refugia hypothesis.

Natural hybridisation is common among species of the Nothofagus genus. N. obliqua hybridises with $N$. alpina, especially in sympatric forests (Donoso et al. 1990; Gallo et al. 1997; Marchelli and Gallo 2000; Gallo 2004). In addition, N. × leonii Espinosa (Donoso and Landrum 1979; Grant and Clement 2004) is recognised as the hybrid between $N$. obliqua and $N$. glauca. Finally, hybridisation between $N$. obliqua and $N$. macrocarpa has been suggested (Vázquez and Rodríguez 1999).

\section{Robles from Lagunas de Epulauquen}

Forests in Lagunas de Epulauquen, growing at $36^{\circ} 49^{\prime} \mathrm{S}$, $71^{\circ} 04^{\prime} \mathrm{W}$ and $1,500 \mathrm{masl}$, in an area of 1,501 ha (Sabatier et al. 2011), are considered the northernmost distribution of $N$. obliqua in Argentina. The nearest cospecific Argentinean forests are located at a distance of $220 \mathrm{~km}$, at Moquehue lake (Sabatier et al. 2011), and are separated by mountain chains, which contribute to the geographical isolation of Lagunas de Epulauquen.

Roble trees from Lagunas de Epulauquen differed from $N$. obliqua trees from other Argentinean populations in leaf size and margin, as well as in branching intensity (Figure 2). To an even greater extent, the bud shape (Figure 3A,B) and cotyledon size (Figure 4) of nurserygrown seedlings from Lagunas de Epulauquen were also different to those from other Argentinean populations of $N$. obliqua. These observations cast doubts on the accepted taxonomic status of the roble population of Lagunas de Epulauquen.

The main goal of this study is to review previous results and present new evidence - based on biochemical, molecular, morphological and architectural data - in order to postulate the hypothesis that the origin of the Lagunas de Epulauquen roble population is different to that of other Argentinean populations of N. obliqua.

\section{Previous evidence supporting the distinctiveness of robles from Lagunas de Epulauquen}

In Chile, $N$. obliqua forests grow approximately $50 \mathrm{~km}$ west of the Lagunas de Epulauquen population, with high mountains in between. Based on pollen fossil analysis, Markgraf (1987) postulated the occurrence of a postglacial introgression within the Lagunas de Epulauquen region, coming from the west. Therefore, a historical connection between the two sides of the Andes Mountains at this latitude can be inferred.

Because of its maternal inheritance in the majority of angiosperm species (Harris and Ingram 1991), chloroplast DNA allows direct estimation of seed-mediated dispersal. Furthermore, the low mutation rate of the chloroplast (Wolfe et al. 1987), which determines its highly conservative nature, helps in the inference of glacial refugia and post-glacial migration routes of glaciation-affected species. Azpilicueta et al. (2009) identified two different cpDNA haplotypes in the Lagunas de Epulauquen population. One of these haplotypes was found in two Chilean populations from similar latitudes (Altos de Vilches at $35^{\circ} 34^{\prime} \mathrm{S}$ and Embalse Bulilleo at $36^{\circ} 22^{\prime} \mathrm{S}$ ), supporting the connection postulated by Markgraf (1987). The other cpDNA haplotype found at Lagunas de Epulauquen was fixed in all the Argentinean populations of $N$. obliqua growing north of Lanin volcano (39 $30^{\prime} \mathrm{S}$ ) (Azpilicueta et al. 2009).

The occurrence of natural hybridisation between $N$. obliqua and other congener species (see $N$. obliqua, previous section) suggested a possible hybrid origin for Lagunas de Epulauquen individuals, and their identification as possible $N$. $\times$ leonii hybrids was even proposed (Gallo et al. 2000). The proximity of potentially hybridising Nothofagus forests in the west (Chile) reinforced this hypothesis. N. obliqua, together with $N$. glauca 


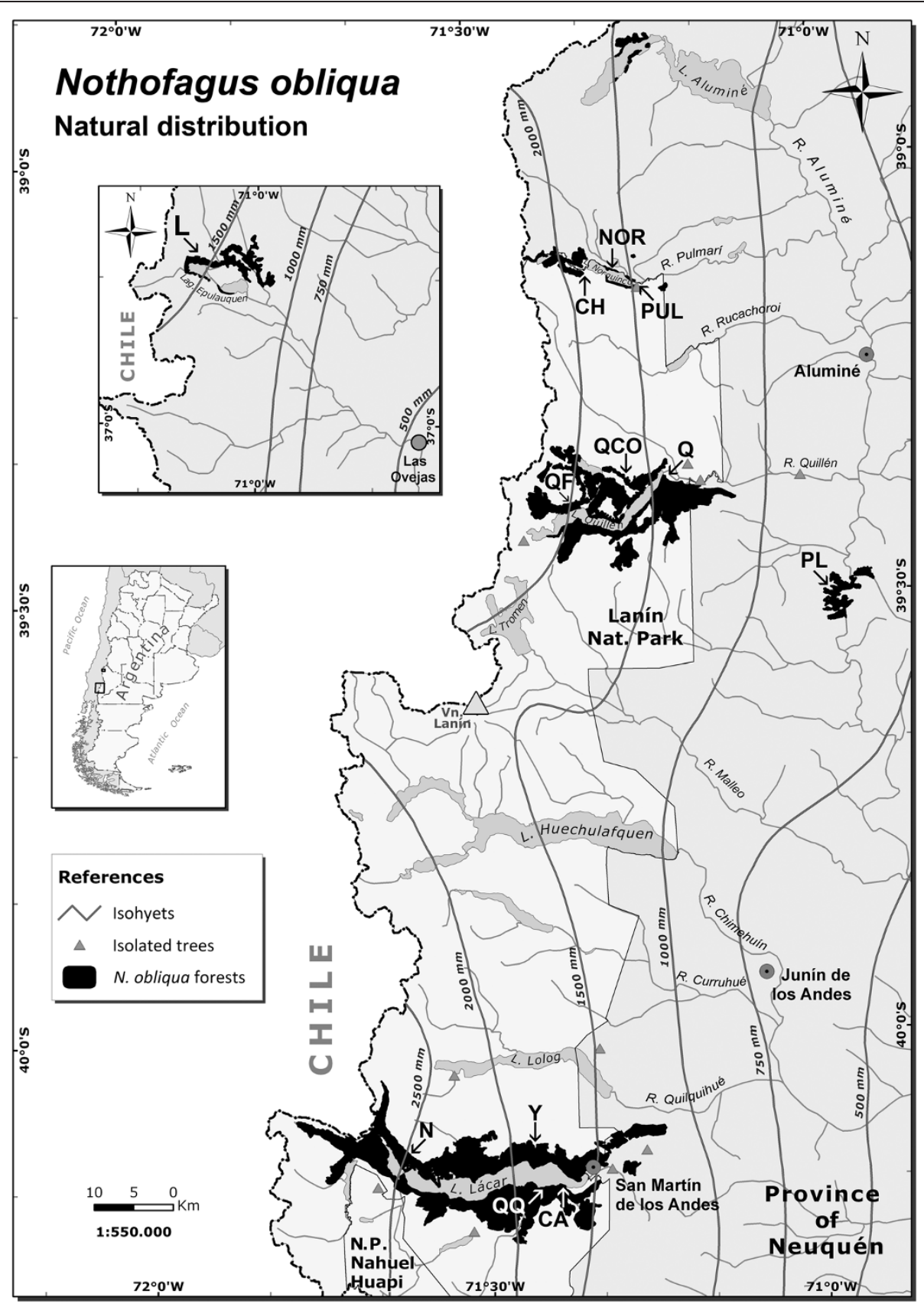

Figure 1 Distribution of Nothofagus obliqua forests in Argentina showing isohyets and sampled populations (Table 2) (from Sabatier et al. 2011).

(Donoso and Landrum 1979; San Martín and Donoso 1995; Le-Quesne and Sandoval 2001), N. alpina and N. macrocarpa (Vázquez and Rodríguez 1999), grow in Chile in Embalse Bulilleo, less than $60 \mathrm{~km}$ from Lagunas de Epulauquen. Accordingly, species-specific isozyme markers revealed a very high proportion of $N$. alpina alleles in the robles of Lagunas de Epulauquen. Adh locus (alcohol dehydrogenase, E.C.1.1.1.1) showed the highest frequency for $A d h-2$ allele - up to then considered as species-specific for N. alpina (Gallo et al. 1997; Marchelli and Gallo 2000) - suggesting the hybrid origin of trees in this population (Azpilicueta and Gallo 2009). This allele had a frequency of $25 \%$, in contrast with frequencies of $<14 \%$ in sympatric populations where hybrids are more likely to occur (Azpilicueta and Gallo 2009). This result was unexpected given the absence of $N$. alpina 


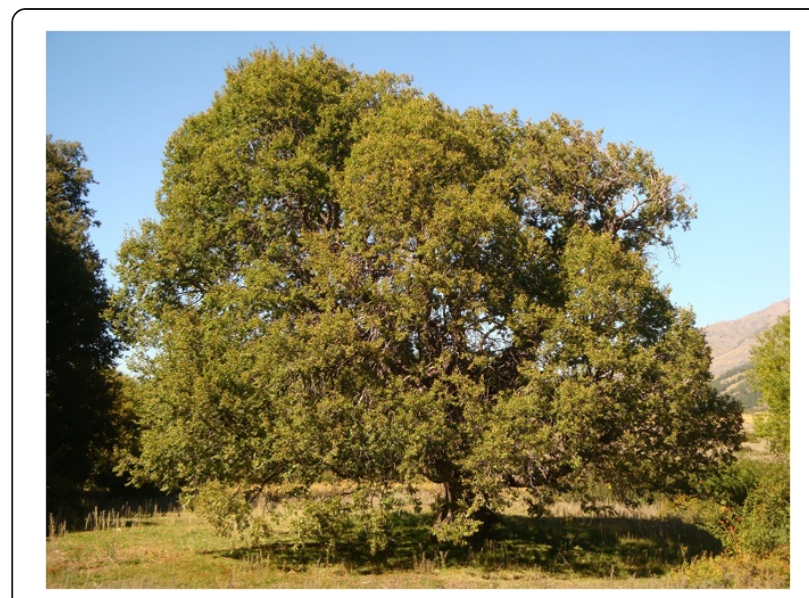

Figure 2 Adult tree from the Lagunas de Epulauquen population.

within the area. In addition, Lagunas de Epulauquen showed the highest number of private microsatellite alleles of all Argentinean populations (five; Azpilicueta et al. 2013), two of which were shared with $N$. alpina. In conclusion, both isozyme and microsatellite markers supported the possible ancestral hybrid origin of Lagunas de Epulauquen individuals with $N$. alpina. The other Nothofagus species growing in the Lagunas de Epulauquen population - Nothofagus antarctica (G. Forst.) Oerst. and Nothofagus pumilio (Poepp. \& Endl.) Krasser (Di Martino et al. 2005) - belong to the sub-genus Nothofagus, and no reports of hybridisation with $N$. obliqua exist.

\section{New evidence supporting the distinctiveness of robles from Lagunas de Epulauquen Biochemical markers: isozymes}

As mentioned, $N$. obliqua also potentially hybridise with $N$. macrocarpa (Vázquez and Rodríguez 1999). In order to provide information about this possible origin for the robles from Lagunas de Epulauquen, four coastal and northern $N$. obliqua Chilean populations were analysed at Adh locus (for methodological details, see Azpilicueta and Gallo 2009). These populations overlap in distribution with $N$. macrocarpa (Ravenna 2002), whereas neither $N$. alpina nor $N$. glauca occur in the sampled area. While the Alto Colorado population - located at the southern limit of the N. macrocarpa distribution - exhibited only $A d h-1$ fixed allele, the three northernmost populations (Til Til, Lampa and Alhué) showed the highest frequencies of the allele $A d h-2$, reaching up to $>50 \%$ (Table 1 ). The particularly high frequency of the allele $A d h-2$ may be indicative of $N$. macrocarpa gene introgression into the $N$. obliqua genome. Thus, this would also constitute evidence for a possible ancestral hybridisation origin of the robles from Lagunas de Epulauquen, this time with $N$. macrocarpa.

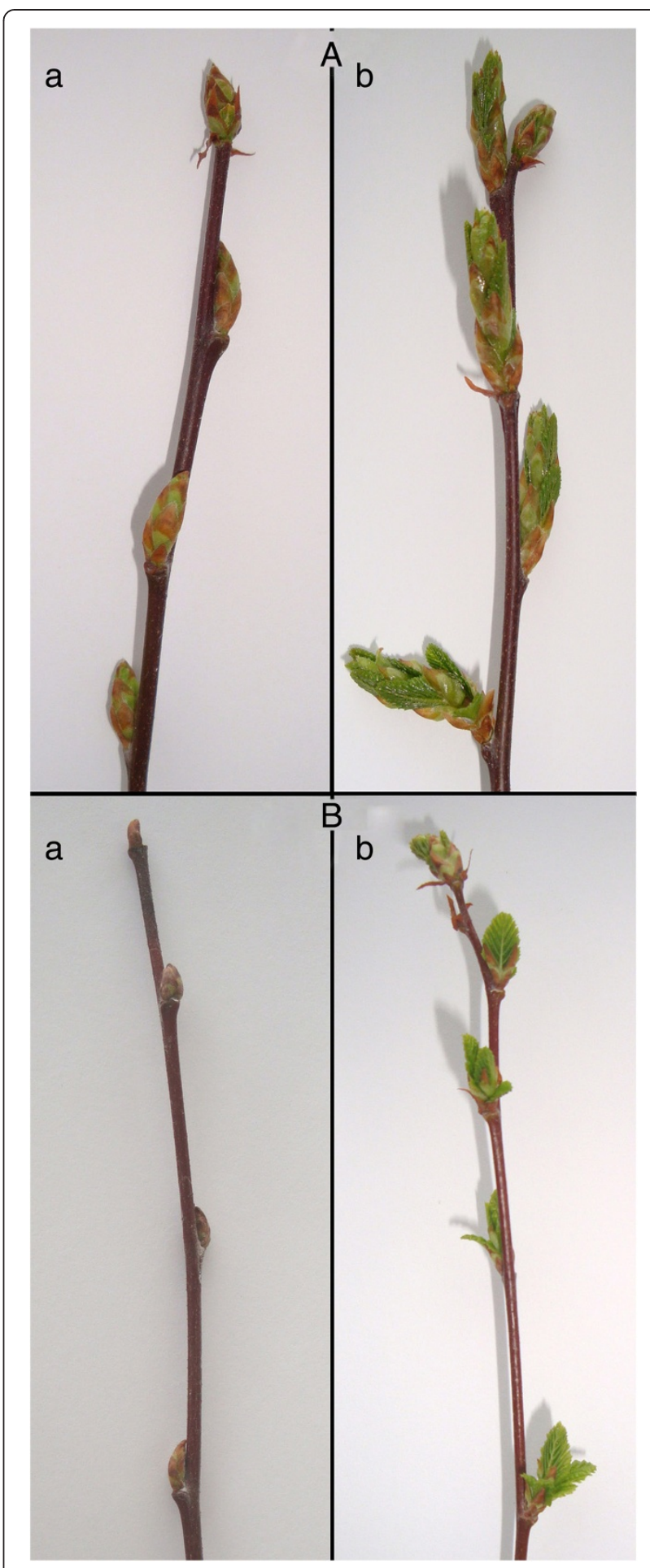

Figure 3 Closed (a) and expanding buds (b) of nursery-grown seedlings. (A) Lagunas de Epulauquen individuals; (B) N. obliqua (Pilolil origin).

\section{Seed characters}

Seed weight and percentage of filled seeds (all Nothofagus species typically have a great proportion of empty seeds 


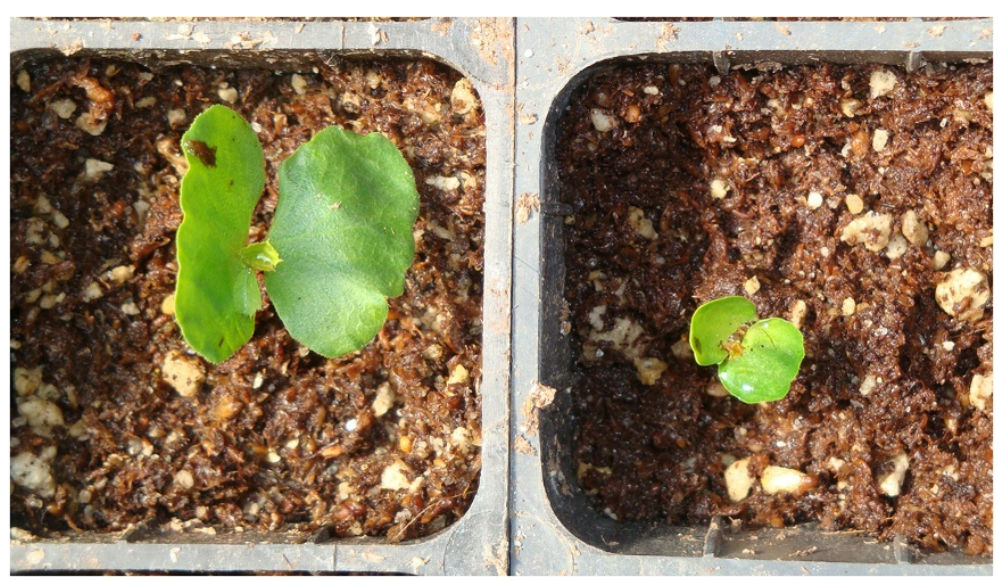

Figure 4 Seedlings from seeds sown in the greenhouse on the same date and under the same environmental conditions. Left: Lagunas de Epulauquen origin; right: Quila Quina origin (Lácar lake watershed).

due to their common parthenocarpic capacity; Poole 1950) were analysed in eight Argentinean populations of $N$. obliqua and germination capacity in five of these populations, including the Lagunas de Epulauquen population (F Barbero, PhD thesis in evaluation). We used between 13 and 15 open-pollination families per population (Table 2). Seed weight was measured in four replicates of 100 seeds per family, whereas percentage of filled seeds was determined based on 50 seeds per family in each population, by dissection and direct observation. Germination capacity was tested with four replicates of 100 seeds per family, under controlled temperature cycles of $25^{\circ}$ $\mathrm{C}$ (for $16 \mathrm{~h}$ ) and $15^{\circ} \mathrm{C}$ (for $8 \mathrm{~h}$ ) over 40 days. Germination capacity was determined as the number of germinated seeds at the end of the experiment.

The Lagunas de Epulauquen population had a higher mean seed weight than the other provenances $(2.24 \mathrm{~g}$ per 100 seeds, as compared to $<1.00 \mathrm{~g}$ for the others; $P$ $<0.001$ ) (Figure 5A). The percentage of filled seeds was also significantly higher $(P<0.05)$ in Lagunas de Epulauquen (57\%) than in the other populations (4\% to $31 \%$ ). Accordingly, a higher germination capacity was detected in Lagunas de Epulauquen (60\%) in comparison with the other populations (13\% to $21 \%$; $P<0.001$; Figure $5 \mathrm{~B})$.

\section{Leaf characters}

Four Argentinean N. obliqua natural populations - including Lagunas de Epulauquen (Table 2) - were essayed in a common garden experiment (INTA EEA Bariloche, $41^{\circ} 7^{\prime} 23^{\prime \prime} \mathrm{S}, 71^{\circ} 14^{\prime} 58^{\prime \prime} \mathrm{W}, 780 \mathrm{masl}$ ) (F Barbero, PhD thesis in evaluation). Ten families per population were analysed in a single-tree plot design with 24 replicates (960 individuals). At 2 years of age and before autumnal senescence, three leaves per sapling were collected from the distal one third of the crown, scanned with 300-dpi resolution, dried for $48 \mathrm{~h}$ at $72^{\circ} \mathrm{C}$ and finally weighed (precision $=0.0001 \mathrm{~g}$ ). Leaf area (LA) was measured using the program ImageJ (URL: http://rsbweb.nih.gov/ij/ download.html), and specific leaf area (SLA) was computed as follows:

$$
\mathrm{SLA}=\frac{\mathrm{LA}\left(\mathrm{cm}^{2}\right)}{\text { Dry mass }(\mathrm{g})}
$$

Lagunas de Epulauquen individuals exhibited the highest mean LA and lowest mean SLA (Figure 6A,B). Significant differences were found between the four populations analysed for LA $(P<0.001)$ and SLA $(P=0.027)$ after applying an analysis of variance using a likelihood

Table 1 Geographical location and allele frequency at Adh locus

\begin{tabular}{|c|c|c|c|c|c|c|}
\hline \multirow[t]{2}{*}{ Population } & \multirow[t]{2}{*}{ Country } & \multirow[t]{2}{*}{ Latitude S } & \multirow[t]{2}{*}{ Longitude W } & \multirow[t]{2}{*}{$N$} & \multicolumn{2}{|c|}{ Adh locus frequency } \\
\hline & & & & & Adh-1 allele & Adh-2 allele \\
\hline Lagunas de Epulauquen & Argentina & $36^{\circ} 49^{\prime}$ & $71^{\circ} 04^{\prime}$ & 120 & 0.742 & 0.258 \\
\hline Til Til & Chile & $33^{\circ} 07^{\prime}$ & $70^{\circ} 58^{\prime}$ & 42 & 0.476 & 0.524 \\
\hline Lampa & Chile & $33^{\circ} 16^{\prime}$ & $70^{\circ} 55^{\prime}$ & 77 & 0.734 & 0.266 \\
\hline Alhué & Chile & $33^{\circ} 57^{\prime}$ & $71^{\circ} 01^{\prime}$ & 65 & 0.508 & 0.492 \\
\hline Alto Colorado & Chile & $34^{\circ} 17^{\prime}$ & $71^{\circ} 46^{\prime}$ & 73 & 1.000 & 0.000 \\
\hline
\end{tabular}

Lagunas de Epulauquen is compared with four coastal populations of roble in northern Chile where Nothofagus macrocarpa is also found.

$N$, sample size (number of individuals analysed). 
Table 2 Geographical and altitudinal characteristics of the origins of roble populations evaluated

\begin{tabular}{|c|c|c|c|c|c|}
\hline Population & ID & Latitude S & Longitude W & Altitude (masl) & Analyses \\
\hline Lagunas de Epulauquen & $L$ & $36^{\circ} 49^{\prime}$ & $71^{\circ} 04^{\prime}$ & 1,500 & slga \\
\hline Ñorquinco Chumpiru & $\mathrm{CH}$ & $39^{\circ} 09^{\prime}$ & $71^{\circ} 15^{\prime}$ & 1,200 & $g$ \\
\hline Ñorquinco Seccional & NOR & $39^{\circ} 09^{\prime}$ & $71^{\circ} 15^{\prime}$ & 1,071 & $\mathrm{sg}$ \\
\hline Ñorquinco Pulmarí & PUL & $39^{\circ} 09^{\prime}$ & $71^{\circ} 12^{\prime}$ & 1,081 & g \\
\hline Quillén Fondo de Lago & QF & $39^{\circ} 26^{\prime}$ & $71^{\circ} 25^{\prime}$ & 1,100 & g \\
\hline Quillén Corral de Bueyes & QCO & $39^{\circ} 22^{\prime}$ & $71^{\circ} 17^{\prime}$ & 1,140 & g \\
\hline Quillén Casa Guardaparque & Q & $39^{\circ} 21^{\prime}$ & $71^{\circ} 13^{\prime}$ & 1,100 & $\mathrm{sg}$ \\
\hline Pilolil & $P L$ & $39^{\circ} 30^{\prime}$ & $70^{\circ} 57^{\prime}$ & 836 & slg \\
\hline Yuco & Y & $40^{\circ} 09^{\prime}$ & $71^{\circ} 30^{\prime}$ & 930 & slg \\
\hline Quila Quina & QQ & $40^{\circ} 10^{\prime}$ & $71^{\circ} 26^{\prime}$ & 983 & sga \\
\hline Nonthué & $N$ & $40^{\circ} 08^{\prime}$ & $71^{\circ} 37^{\prime}$ & 680 & s \\
\hline Catritre & $C A$ & $40^{\circ} 10^{\prime}$ & $71^{\circ} 24^{\prime}$ & 650 & sl \\
\hline
\end{tabular}

g, growth traits; a, architectural features; s, seed characters; I, leaf morphological characters.

ratio test (LRT). The Lagunas de Epulauquen population was different from all the other three populations for LA and from one of them for SLA.

\section{Architectural features}

Trunk growth and branching were compared for a total of 244 8-year-old roble individuals from Lagunas de Epulauquen and a southern Argentinean population (Quila Quina $40^{\circ} 10^{\prime} \mathrm{S}, 71^{\circ} 26^{\prime} \mathrm{W}$ ), grown from germination in a common garden (Table 2). For Lagunas de Epulauquen, seven open-pollination families were differentiated (L1 to L7), consisting of 21 to 25 individuals per family. For Quila Quina, two families (QQ1 and QQ2) and two groups of families (QQ3 and QQ4) were differentiated, which had 13 to 43 individuals per family or group of families. For each individual, the length (with a measuring tape), basal diameter (with digital callipers) and number of green leaves of the last but one annual shoot of the trunk (i.e. the stem portion extended in the year preceding the year of measuring) were registered. For each node of each annual shoot, the phyllotactic pattern and the presence/absence of axillary branch were recorded. In Nothofagus spp., phyllotaxis may adopt one of two conditions: alternate distichous (leaves arranged in two lines along the stem) or alternate tristichous (leaves arranged along three lines). Regarding branching, we recorded the following: presence/absence of an immediate branch (i.e. a branch
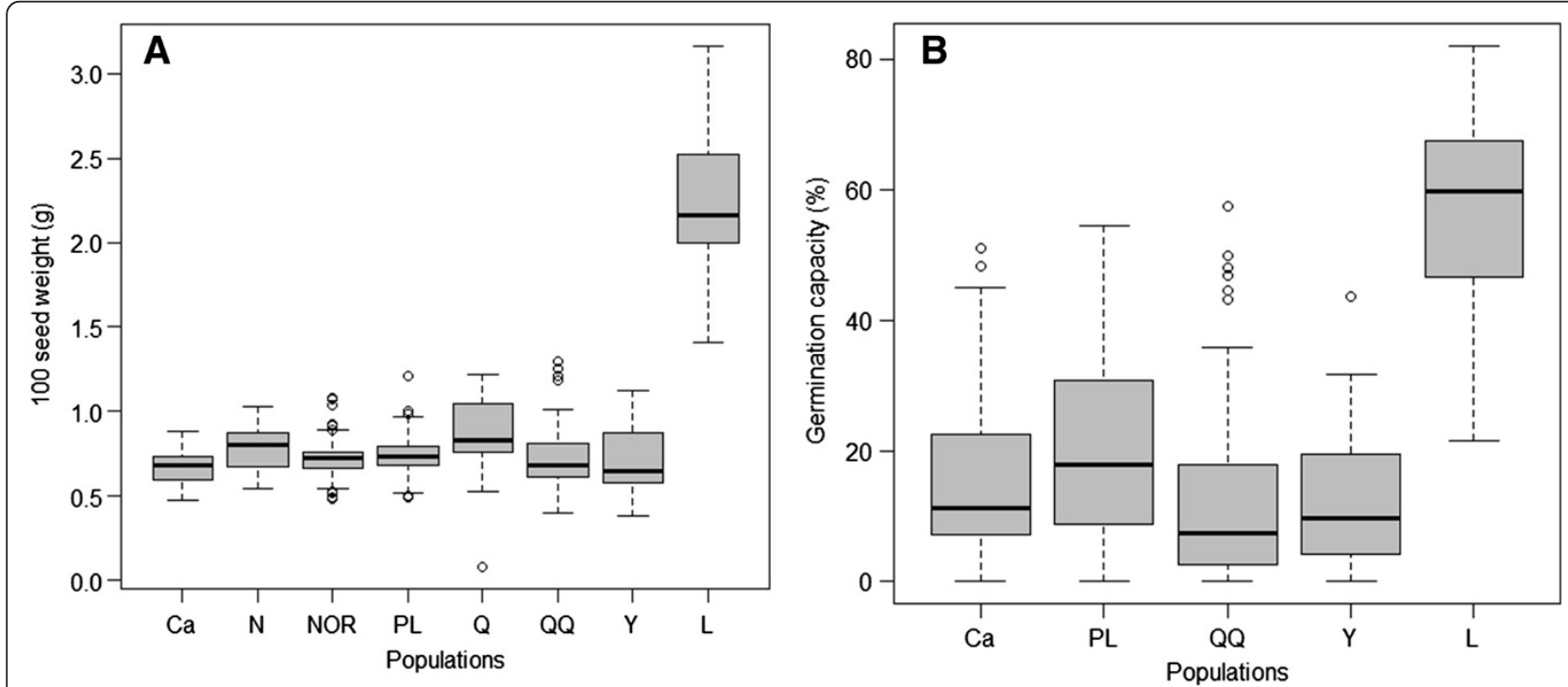

Figure 5 Boxplots of dispersion and symmetry for the characters. (A) Weight of 100 seeds from eight Argentinean Nothofagus obliqua origins, including Lagunas de Epulauquen; (B) germination capacity of five Argentinean origins of N. obliqua, including Lagunas de Epulauquen. The complete name and geographical location of the populations analysed are shown in Table 2. 

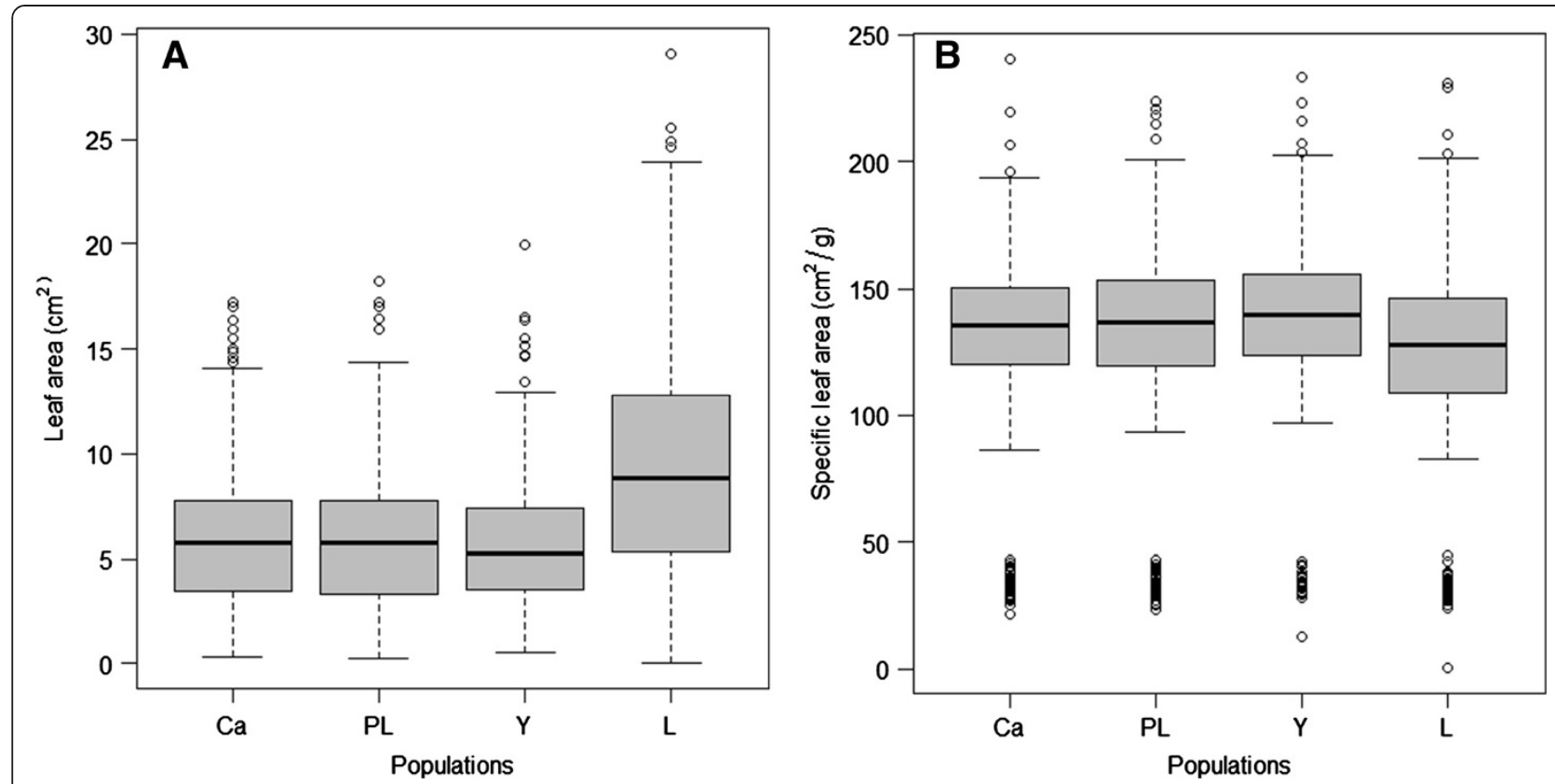

Figure 6 Boxplots for leaf area and specific leaf area in four origins of $\boldsymbol{N}$. obliqua. (A) leaf area; (B) specific leaf area. The name and geographical location of the populations analysed are shown in Table 2.

developed as the annual shoot extended) or a delayed branch (i.e. a branch developed 1 year after the extension of the bearing annual shoot). Analysis of variance for unbalanced designs was applied to all annual shoots so as to compare origins (Lagunas de Epulauquen and Quila Quina, fixed factor) and families (random factor, nested within each origin). Comparisons between origins regarding phyllotaxis and branching were performed graphically. For each stem node, numbered from the stem's proximal end, we computed the proportions of nodes with distichous and tristichous phyllotaxis and the proportions of nodes with immediate and delayed branches.
The mean basal diameter of the shoots did not differ between origins $(F=1.1, P>0.1)$ (Table 3$)$. Both the length (Figure 7) and the number of leaves of the annual shoots were higher for Lagunas de Epulauquen than for Quila Quina $(P<0.001$ and $P<0.001$, respectively; Table 3). Annual shoots had a higher length/diameter ratio (i.e. more slender shoots; $P<0.001$ ) and length/ number of leaves relationship (i.e. longer mean internode length; $P<0.001$ ) for Lagunas de Epulauquen than for Quila Quina. Significant family effects on variations in diameter $(P<0.01)$ and in length/diameter relationship $(P<0.05)$ were detected. Phyllotaxis was predominantly

Table 3 Morphological attributes of annual shoots of 7-year-old roble plants

\begin{tabular}{|c|c|c|c|c|c|c|}
\hline Shoot trait & Population & Mean & S.E. & Var & Min & $\operatorname{Max}$ \\
\hline \multirow[t]{2}{*}{ Basal diameter (mm) } & Lagunas de Epulauquen & 9.2 & 0.17 & 4.58 & 5.5 & $\overline{18.0}$ \\
\hline & Quila Quina & 8.8 & 0.21 & 4.21 & 5.6 & 16.2 \\
\hline \multirow[t]{2}{*}{ Total length $(\mathrm{cm})$} & Lagunas de Epulauquen & 73.4 & 1.72 & 450.43 & 22.0 & 128.0 \\
\hline & Quila Quina & 46.6 & 1.32 & 160.11 & 23.0 & 73.5 \\
\hline \multirow[t]{2}{*}{ Number of leaves } & Lagunas de Epulauquen & 25 & 0.5 & 38.7 & 10 & 42 \\
\hline & Quila Quina & 22 & 0.4 & 15.5 & 14 & 35 \\
\hline \multirow[t]{2}{*}{ Length/diameter (cm/mm) } & Lagunas de Epulauquen & 8.1 & 0.18 & 4.68 & 2.5 & 13.0 \\
\hline & Quila Quina & 5.4 & 0.15 & 1.99 & 2.3 & 9.2 \\
\hline \multirow[t]{2}{*}{ Mean internode length $(\mathrm{cm})$} & Lagunas de Epulauquen & 2.9 & 0.04 & 0.19 & 1.8 & 4.3 \\
\hline & Quila Quina & 2.1 & 0.04 & 0.14 & 1.4 & 3.1 \\
\hline
\end{tabular}

Mean, standard error (S.E), variance (Var), minimum value (Min) and maximum value (Max) from Lagunas de Epulauquen (152 trees) and Quila Quina (92 trees) are shown. 


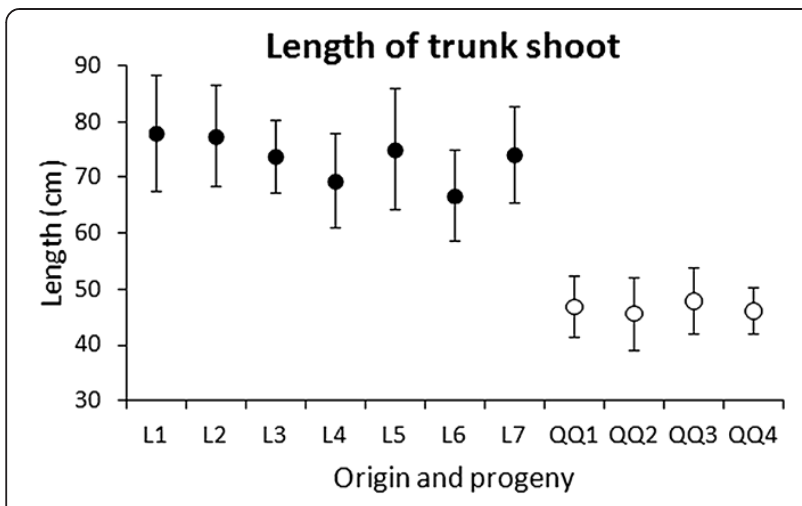

Figure 7 Mean ( \pm standard error) of annual trunk shoot length developed by 7-year-old roble plants. Lagunas de Epulauquen ( $L$ ) and Quila Quina (QQ) origins are divided into progenies for each origin (indicated by numbers).

distichous for the proximal end of the annual shoots of both origins; a progressively higher proportion of annual shoots - especially those of Lagunas de Epulauquen tended to have tristichous phyllotaxis toward the shoot's distal end (Figure 8A,B). For both origins, the proportion of branched nodes, in particular those with a delayed branch, increased from the fourth most proximal node to the annual shoot's distal end (Figure 8C,D). A high proportion of nodes with immediate branches and a corresponding decrease in the proportion of delayed branches were registered in intermediate nodes for annual shoots of Quila Quina (Figure 8C,D). For Lagunas de Epulauquen, in contrast, the proportion of annual shoots with immediate branches was very low.

\section{Survival and height growth in field trials}

During 2004, a provenance field trial - including the Lagunas de Epulauquen population - was installed at Lácar lake, Argentina $\left(40^{\circ} 07^{\prime} \mathrm{S}\right.$ to $\left.71^{\circ} 28^{\prime} \mathrm{W}\right)$, beneath a mixed forest of $N$. obliqua, $N$. alpina and Nothofagus dombeyi (Mirb.) Oerst. The site is characterised by volcanic soils and a mean precipitation of 2,200 mm/year. The essayed populations and their geographical locations are shown in Table 2. We used a randomised complete block design (RCBD) with a plot size of nine individuals. Survival and height were measured at the first and fourth years from trial installation. Both height measures were used to calculate growth rate relative to the measurement at the first year and later transformed with the logarithm 10 for variance analysis; for multiple mean comparisons, we used a Tukey test.

Tree survival was high $(94 \%$ and $91 \%$ at the first and fourth years after installation, respectively), which was as expected due to the optimal environmental conditions for $N$. obliqua in the trial site. The population effect gave rise to significant differences for the first year $(P<0.001)$ and for the fourth year $(P<0.001)$ regarding total height and $\log$ relative growth $(P<0.001$; Figure 9A,B,C, respectively).

Lagunas de Epulauquen had the lowest total height (at both the first and fourth years) and presented significant differences to the other analysed populations, except for Pulmarí (PUL) and Quillén Fondo de Lago (QF), which correspond to the species' northern distribution areas. On the other hand, Lagunas de Epulauquen exhibited the highest relative growth rate, significantly different
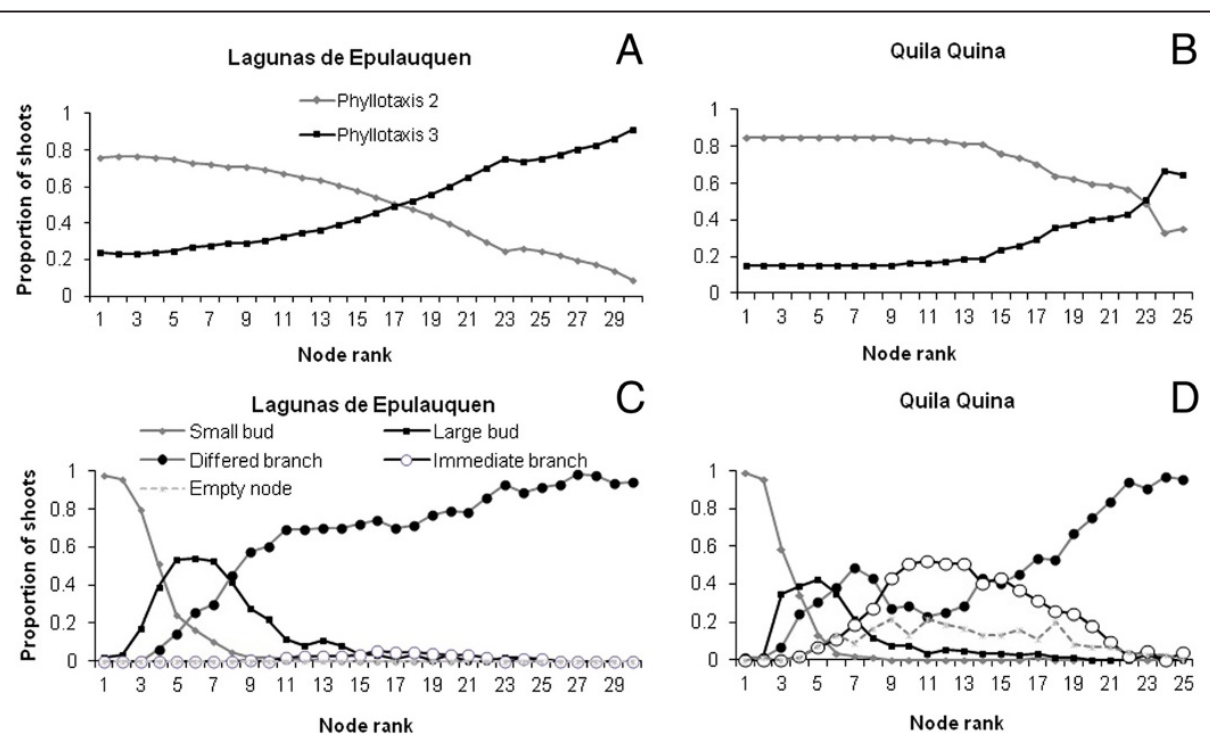

Figure 8 Phyllotaxis and branching in annual shoots of roble plants. (A,B) Distichous (2) or tristichous (3) phyllotaxis; (C,D) with an immediate or differed branch or with no branch in each axillary position. Nodes counted from the proximal end of the annual shoot. Plants from Lagunas de Epulauquen and Quila Quina are shown separately. 

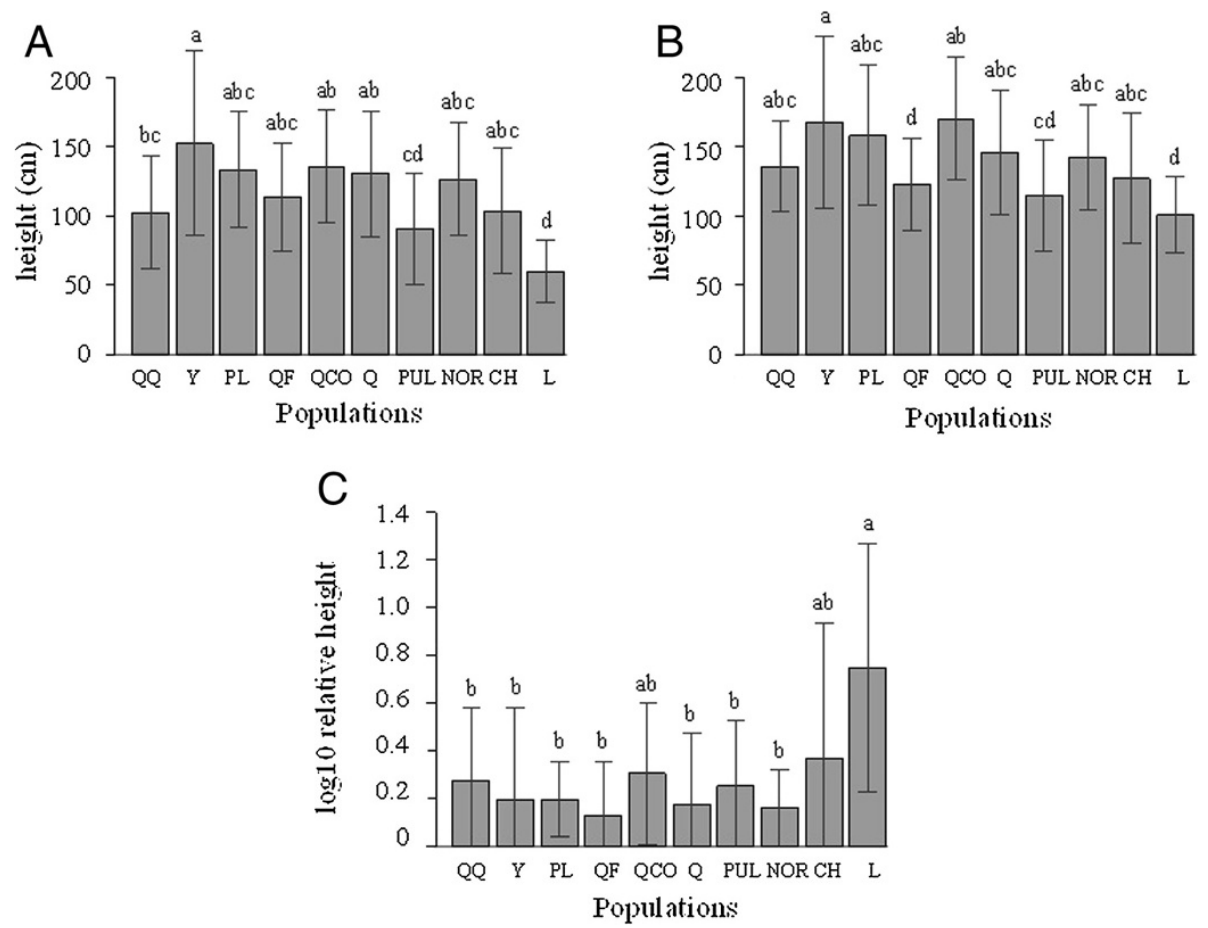

Figure 9 Mean height values ( \pm standard error) by population. (A) at the first and (B) fourth years after plantation and $(\mathbf{C})$ log 10 of the relative growth in height between the first and fourth years. Equal letters above the bar indicate statistically similar means ( $a=0.05)$. The name and geographical location of the populations analysed are shown in Table 2.

from all the other populations except Chumpiru $(\mathrm{CH})$ and Quillén Corral de Bueyes (QCO).

\section{Discussion}

The evidence for the genetically distinctive character of robles in the Lagunas de Epulauquen population compared to other Argentinean N. obliqua forests is supported in the present revision by both previous and new information. Lagunas de Epulauquen individuals show differences at biochemical, molecular, morphological and architectural levels. Molecular (Azpilicueta et al. 2009) and palynological (Markgraf 1987) data suggested that the Lagunas de Epulauquen population could have originated as an introgression from the western side of the Andean Cordillera during post-glacial re-colonisation. The presence in Lagunas de Epulauquen of a chloroplast DNA haplotype private to western populations reinforces this hypothesis. In agreement with this, Markgraf et al. (2009) dated the forests of this region as 5,000 years BP, while an older origin was postulated for western refugia (Heusser 1983; Heusser et al. 1999; Villagrán 1991; Villagrán et al. 1995). The co-existence of $N$. glauca, $N$. macrocarpa, $N$. alpina and $N$. obliqua to the west suggests the possibility of a hybrid origin for robles from Lagunas de Epulauquen. Therefore, post-glacial history together with ancient hybridisation processes could stand as the main reasons for the present distinctiveness of the roble population in Lagunas de Epulauquen.

The geographical isolation of the Lagunas de Epulauquen population predicts genetic drift and inbreeding processes. However, a high level of genetic variation was detected with all genetic markers (isozymes: Azpilicueta and Gallo 2009; chloroplast DNA: Azpilicueta et al. 2009; microsatellites: Azpilicueta et al. 2013). It is possible that past hybridisation increased genetic diversity by providing new genetic variants. Moreover, long-distance pollen gene flow can rapidly restore genetic diversity (Hampe et al. 2013). Although, at least for $N$. alpina, most pollen disperses at short distances, a high potential for long-distance dispersal was reported (Marchelli et al. 2012).

The high frequency of the allele $A d h-2$ found in coastal and northern Chilean $N$. obliqua populations where $N$. macrocarpa grows casts doubt on the origin of this allele. Neither $N$. alpina nor $N$. glauca grow within this northern area; therefore, the $A d h-2$ allelic variant could come from $N$. macrocarpa. The phylogenetic affinity between $N$. macrocarpa and $N$. alpina can explain the occurrence of common alleles in these two species. Vázquez and Rodríguez (1999) reported a closer morphological affinity between $N$. macrocarpa and $N$. alpina than between these two species and $N$. obliqua. Apparently, $N$. macrocarpa has been wrongly associated with $N$. obliqua, since both morphological and ecological (altitudinal niche) 
data support a closer relationship between $N$. macrocarpa and $N$. alpina (Vázquez and Rodríguez 1999). However, an alternative interpretation must be considered. Among the drawbacks of isozymes is the inability to detect variants in the DNA sequence that produces isozymes with no changes in electromorph mobility. Thus, the $A d h-2$ allelic variant observed in gels of $N$. obliqua, $N$. macrocarpa and $N$. alpina, although identical, could be the expression of different DNA sequences. The sequencing of the gene coding for the Adh enzyme should help in the precise identification of $A d h-2$ allele and its species origin.

The large seed size observed in Lagunas de Epulauquen could be a consequence of genecological variation, as found for N. obliqua in Chile (Donoso 1979). The largest seed size of the northernmost $N$. obliqua populations was explained as an adaptation to xeric environments within a wide latitudinal species cline. However, since $N$. macrocarpa was only later recognised as a separate species, it is possible that the sample in Donoso's study consisted of seeds from the two species (or included hybrids with $N$. macrocarpa). The results of our study could then be explained by clinal variation together with ancient hybridisation with N. macrocarpa.

The differences regarding leaf characters (leaf area and specific leaf area) between robles from Lagunas de Epulauquen and N. obliqua plants from other Argentinean populations reinforced the distinctiveness of the former population. Previous non-systematic field and nursery observations have now been confirmed based on these results.

Clear differences in length, number of leaves, mean internode length and the branching pattern of annual shoots were found between robles from Lagunas de Epulauquen and those from Quila Quina. With regard to these traits, Quila Quina plants resembled those from other areas within the distribution of $N$. obliqua in Argentina (e.g. Puntieri et al. 2006). In annual shoots of $N$. alpina, as in those of roble plants from Lagunas de Epulauquen, the frequency of development of immediate branches is relatively low and internodes are long compared to those of annual shoots in similar architectural positions on $N$. obliqua plants (Barthélémy et al. 1999). Recent observations confirmed that the architectural traits that distinguished nursery-grown Lagunas de Epulauquen plants from Quila Quina ones also occur in field conditions. Architectural studies incorporating the closely related Nothofagus entities considered in the present study (N. macrocarpa, N. glauca and N. × leonii), little known in this regard, may provide a clearer picture of the evolution of morpho-architectural traits in plants.

Height growth analysis showed that Lagunas de Epulauquen individuals exhibited low stem height - at both the first and fourth years - but, notwithstanding, the highest height growth rate compared to $N$. obliqua plants from other origins. All results coming from quantitative trait analyses may be associated with environmental conditions. In this regard, it must be highlighted that the roble population at Lagunas de Epulauquen is located at a relatively high altitudinal range compared to other roble populations from Argentina: from 1,500 to 1,700 masl, as opposed to the 600 to 1,200 masl range for other roble populations in Argentina. This environmental feature, together with the current genetic isolation of this population, leads us to put forward a hypothesis involving adaptation processes. New quantitative traits, especially phenological ones, should be considered in order to explore this alternative.

\section{Conclusions}

The glacial history of Patagonia - with valley-type glaciers at northern latitudes leaving ice-free areas and re-colonised southern regions - probably promoted the high genetically divergent evolution of $N$. obliqua forests as proposed by Donoso et al. (2004). The profusion of races, varieties, ecotypes and sub-species found nowadays in $N$. obliqua forests supports this idea. The results of the present study also provide evidence supporting the idea that the isolated roble population at Lagunas de Epulauquen shared (unlike other roble populations in Argentina) a common glacial history with Nothofagus populations from low-ice-impact areas in Chile, which could have resulted in a distinctive evolutionary process.

Future analyses of vegetative and reproductive characters in $N$. alpina, N. glauca and N. macrocarpa together with other $N$. obliqua populations could probably help in determining the taxonomic identity of the Nothofagus trees in Lagunas de Epulauquen. Architectural variation during early ontogenetic stages as well as phenological traits should be included in these studies. Sequencing of ITS nuclear ribosomal gene (internal transcript unit) and comparison with the results obtained by Manos (1997) and Acosta and Premoli (2010) should provide additional and valuable information for taxonomic identification through phylogenetic reconstruction.

\section{The conservation value of Lagunas de Epulauquen}

The Lagunas de Epulauquen area is of remarkable conservation value due to the diversity of its flora, which includes species from xeric environments (e.g. Mulinum spinosum), species typical of Valdivian forests (e.g. Lomatia ferruginea) and endemic species (e.g. Puya alpestris) (Alfonso and Prinna 2009; Di Martino et al. 2005). Most of the Lagunas de Epulauquen ecosystem - with a surface area of 7,450 ha - has been included within a provincial protected area called Reserva Lagunas de Epulauquen (Neuquén province), created in 1973. However, the limits of this reserve do not follow ecological criteria and, as a consequence, some $N$. obliqua forests lie outside the protected area, on private land. The limits of the protected 
area should be re-considered and sustainable management policies should be applied so as to promote forest regeneration. Conservation of this population's genetic pool could be the key to securing its adaptative capacity and, consequently, its persistence, especially considering the ongoing global climate change.

\section{Competing interests}

The authors declare that they have no competing interests.

\section{Authors' contributions}

MMA conceived and designed the study and prepared the first version of the manuscript, MMA and PM carried out the molecular genetic studies and their analysis, FB and MJP carried out the seed and leaf character analyses, JP carried out the architectural analysis, AMM and MMA carried out the fitness analysis and LAG coordinated the research group and helped in the design of the study; all authors helped in writing the manuscript. All authors read and approved the final manuscript.

\section{Acknowledgements}

Thanks are due to Sebastián Di Martino for allowing the collection of samples at Lagunas de Epulauquen and to Soledad Ghirardi, Abel Martínez, Mario Huentú, Liliana Lozano and Sebastián Zuki for their valuable field and nursery work. This work was financially supported by projects PIP 112200801 01026 (CONICET, Argentina), PNFOR044321 (INTA, Argentina), PNFOR044001 (INTA, Argentina) and Subprograma Nothofagus (PROMEF - Ministerio Agricultura Ganadería y Pesca de Argentina).

\section{Author details}

${ }^{1}$ INTA (Instituto Nacional de Tecnología Agropecuaria), EEA Bariloche, Modesta Victoria 4450, 8400 Bariloche, Argentina. ${ }^{2}$ CONICET (Consejo Nacional de Investigaciones Científicas y Técnicas), 8400 Bariloche, Argentina. ${ }^{3}$ UNRN (Universidad Nacional de Río Negro), Av. San Martín 2650, 8430 El Bolsón, Argentina.

Received: 2 June 2014 Accepted: 22 October 2014 Published online: 02 December 2014

\section{References}

Acosta MC, Premoli AC (2010) Evidence of chloroplast capture in South American Nothofagus (subgenus Nothofagus, Nothofagaceae). Mol Phylogenet Evol $54: 235-242$

Alfonso G, Prinna A (2009) Catálogo florístico de la Reserva lagunas de Epu Lauquen, Departamento Minas, Provincia de Neuquén, Argentina. Ernstia 19:109-136

Allnut TR, Newton AC, Premoli A, Lara A (2003) Genetic variation in the threatened South American conifer Pilgerodendron uviferum (Cupressaceae), detected using RAPD markers. Biol Conserv 114:245-253

Araya L, Oyarzún MV (2000) Descripción de los bosques de N. alpina y N. obliqua en Chile. In: Ipinza Carmona R, Gutiérrez Caro B, Emhart Schmidt V (eds) Domesticación y mejora genética de raulí y roble. UACH/INFOR, Valdivia

Azpilicueta MM, Gallo LA (2009) Shaping forces modelling genetic variation patterns in the naturally fragmented forests of a South American beech. Biochem Sys Ecol 37:290-297

Azpilicueta MM, Marchelli P, Gallo LA (2009) The effects of Quaternary glaciations in Patagonia as evidenced by chloroplast DNA phylogeography of Southern beech Nothofagus obliqua. Tree Genet Genomes 5:561-571

Azpilicueta MM, Gallo LA, van Zonneveld M, Thomas E, Moreno C, Marchelli P (2013) Management of Nothofagus genetic resources: definition of genetic zones based on a combination of nuclear and chloroplast marker data. For Ecol Manag 302:414-424

Barthélémy D, Puntieri JG, Brion C, Raffaele E, Marino J, Martinez P (1999) Morfología de las unidades estructurales y modo de desarrollo básico de especies Patagónicas de Nothofagus (Fagaceae). Bol Soc Argent Bot 34:29-38

Bekessy SA, Allnut TR, Premoli AC, Lara A, Ennos RA, Burgman MA, Cortes M, Newton AC (2002) Genetic variation in the vulnerable and endemic monkey puzzle tree, detected using RAPDs. Heredity 88:243-249

Di Martino S, Maletti EJ, Mazieres AV (2005) Plan General de Manejo del Área Natural Protegida Epu Lauquen. Dirección General de Áreas Naturales
Protegidas, Ministerio de Producción y Turismo, Provincia de Neuquén, Argentina

Donoso C (1979) Genecological differentiation in Nothofagus obliqua (Mirb.) Oerst. in Chile. For Ecol Manag 2:53-66

Donoso C, Landrum LR (1979) Nothofagus leonii Espinosa, a natural hybrid between Nothofagus obliqua (Mirb.) Oerst. and Nothofagus glauca (Phil.) Krasser. N Z J Bot 17:353-360

Donoso C, Morales J, Romero M (1990) Hibridación natural entre roble (Nothofagus obliqua (Mirb.) Oerst.) y raulí (N. alpina (Poepp. et Endl.) Oerst.) en bosques del sur de Chile. Revista Chilena de Historia Natural 63:49-60

Donoso C, Gallo LA, Donoso P, Azpilicueta MM (2004) Variación en Nothofagus obliqua (Mirb.) Oerst. (Roble, Coyán, Hualle o Pellín). In: Donoso C, Premoli A, Gallo L, Ipinza R (eds) Variación intraespecífica en las especies arbóreas de los bosques templados de Chile y Argentina. Editorial Universitaria, Santiago de Chile

Gallo LA (2004) Modelo conceptual sobre hibridación natural interespecífica entre Nothofagus nervosa y N. obliqua. In: Donoso C, Premoli A, Gallo L, Ipinza R (eds) Variación intraespecífica en las especies arbóreas de los bosques templados de Chile y Argentina. Editorial Universitaria, Santiago de Chile

Gallo LA, Marchelli P, Breitembücher A (1997) Morphological and allozymic evidence of natural hybridization between two Southern beeches (Nothofagus spp.) and its relation to heterozygosity and height growth. For Genet 4:15-23

Gallo L, Marchelli P, Crego P, Oudkerk L, Breitembücher A, Peñalba M, Chauchard L, Maresca L, Cuerpo Guardaparques PN Lanín, PN Nahuel Huapi (2000) Distribución y variación genética en características seminales y adaptativas de poblaciones y progenies de Raulí en Argentina. In: Ipinza Carmona R, Gutiérrez Caro B, Emhart Schmidt V (eds) Domesticación y mejora genética de raulí y roble. UACH/INFOR, Valdivia

Grant ML, Clement EJ (2004) Clarification of the name Nothofagus alpina and a new epithet for a Nothofagus hybrid. Bot J Linn Soc 146:447-451

Hampe A, Pemonge M-H, Petit RJ (2013) Efficient mitigation of founder effects during the establishment of a leading-edge oak population. Proc Biol Sci B 280:1070

Harris SA, Ingram R (1991) Chloroplast DNA and biosystematics: the effects of intra-specific diversity and plastid transmission. Taxon 14:393-412

Heenan PB, Smissen RD (2013) Revised circumscription of Nothofagus and recognition of the segregate genera Fuscospora, Lophozonia, and Trisyngyne (Nothofagaceae). Phytotaxa 146:1-31

Heusser CJ (1983) Quaternary pollen record from Laguna de Tagua Tagua, Chile. Science 219:1429-1432

Heusser CJ, Heusser LE, Lowell TV (1999) Paleoecology of the southern Chilean lake district-Isla de Chiloé during middle-late Llanquihue glaciation and deglaciation. Geogr Ann 81A:231-284

Hill RS, Jordan GJ (1993) The evolutionary history of Nothofagus (Nothofagaceae). Aust Syst Bot 6:111-126

Hill RS, Read J (1991) A revised infrageneric classification of Nothofagus (Fagaceae). Bot J Linn Soc 105:37-72

Le-Quesne C, Sandoval L (2001) Extensión del límite sur para Nothofagus glauca (Phil.) Krasser. Gayana Bot 58:139-142

Manos PS (1997) Systematics of Nothofagus (Nothofagaceae) based on rDNA spacer sequences (ITS): taxonomic congruence with morphology and plastid sequences. Am J Bot 84:1137-1155

Marchelli P, Gallo LA (2000) Genetic analysis of isozyme variants in open pollinated families of southern beech Nothofagus nervosa (Phil.) Dim. et Mil. Silvae Genetica 49:90-98

Marchelli P, Gallo LA, Scholz F, Ziegenhagen B (1998) Chloroplast DNA markers reveal a geographical divide across Argentinean southern beech Nothofagus nervosa (Phil.) Dim. et Mil. distribution area. Theor Appl Genet 97:642-646

Marchelli P, Baier C, Mengel C, Ziegenhagen B, Gallo LA (2010) Biogeographic history of the threatened species Araucaria araucana (Molina) K. Koch and implications for conservation: a case study with organelle DNA markers. Conserv Genet 11:951-963

Marchelli P, Smouse P, Gallo LA (2012) Short-distance pollen dispersal for an outcrossed, wind-pollinated southern beech (Nothofagus nervosa (Phil.) Dim. et Mil.). Tree Genet Genomes 8:1123-1134

Markgraf V (1987) Paleoenvironmental changes at the northern limit of the subantarctic Nothofagus forests, lat. 37º , Argentina. Quat Res 28:119-129

Markgraf V, MacGlone M, Hope G (1995) Neogene paleoenvironmental and paleoclimatic change in southern temperate ecosystems - a southern perspective. Trends Ecol Evolut 10:143-147 
Markgraf V, Whitlock C, Anderson RS, Garcia A (2009) Late Quaternary vegetation and fire history in the northernmost forest region: Mallín Vaca Lauquen, Neuquén province, Argentina. J Quat Sci 24:248-258

Martin PG, Dowd JM (1993) Using sequences of rbcL to study phylogeny and biogeography of Nothofagus species. Aust Syst Bot 6:441-447

Pastorino MJ, Gallo LA (2002) Quaternary evolutionary history of Austrocedrus chilensis, a cypress native to the Andean-Patagonian forest. J Biogeogr 29:1167-1178

Poole AL (1950) Studies of New Zealand Nothofagus species. 2 Nut and cupule development. T Roy Soc NZ 78:502-508

Premoli AC, Kitzberger T, Veblen TT (2000) Isozyme variation and recent biogeographical history of the long-lived conifer Fitzroya cupressoides. J Biogeogr 27:251-260

Puntieri JG, Grosfeld J, Stecconi M, Brion C, Azpilicueta MM, Gallo LA (2006) Desarrollo temprano del roble (Nothofagus obliqua): un análisis arquitectural de procedencias de Argentina. Bosque 27:44-51

Rabassa J, Clapperton CM (1990) Quaternary glaciations in the southern Andes. Quat Sci Rev 9:153-174

Ravenna P (2002) Nothofagus macrocarpa y Nothofagus rutila (Fagaceae), dos especies diferentes. Onira 7:57-60

Sabatier Y, Azpilicueta MM, Marchelli P, González-Peñalba M, Lozano L, García L, Martinez A, Gallo LA, Umaña F, Bran D, Pastorino MJ (2011) Distribución natural de Nothofagus alpina y Nothofagus obliqua (Nothofagaceae) en Argentina, dos especies de primera importancia forestal de los bosques templados norpatagónicos. Bol Soc Argent Bot 46:131-138

San Martín J, Donoso C (1995) Estructura florística e impacto antrópico del bosque maulino de Chile. In: Armesto JJ, Villagrán C, Arroyo MK (eds) Ecología de los bosques nativos de Chile. Editorial Universitaria, Santiago de Chile

Vázquez FM, Rodríguez RA (1999) A new subspecies and two new combinations of Nothofagus Blume (Nothofagaceae) from Chile. Bot J Linn Soc 129:75-83

Veblen TT, Donoso C, Kitzberger T, Rebertus AJ (1996) Ecology of southern Chilean and Argentinean Nothofagus forests. In: Veblen TT, Hill RS, Read J (eds) The ecology of biogeography of Nothofagus forests. Yale University Press, New Haven and London

Veit H, Garleff K (1995) Evolución del paisaje cuaternario y los suelos en Chile central-sur. In: Armesto JJ, Villagrán C, Kalin Arroyo M (eds) Ecología de los bosques nativos de Chile. Editorial Universitaria, Santiago de Chile

Villagrán C (1991) Historia de los bosques templados del sur de Chile durante el Tardiglacial y Postglacial. Rev Chil Hist Nat 64:447-460

Villagrán C, Moreno P, Villa R (1995) Antecedentes palinológicos acerca de la historia cuaternaria de los bosques chilenos. In: Armesto JJ, Villagrán C, Kalin Arroyo M (eds) Ecología de los bosques nativos de Chile. Editorial Universitaria, Santiago de Chile

Wolfe KH, Li W-H, Sharp PM (1987) Rates of nucleotide substitution vary greatly among plant mitochondrial, chloroplast and nuclear DNAs. Proc Natl Acad Sci U S A 84:9054-9058

doi:10.1186/s40693-014-0024-0

Cite this article as: Azpilicueta et al:: Robles in Lagunas de Epulauquen Argentina: previous and recent evidence of their distinctive character. Revista Chilena de Historia Natural 2014 87:24.

\section{Submit your manuscript to a SpringerOpen ${ }^{\odot}$ journal and benefit from:}

- Convenient online submission

- Rigorous peer review

- Immediate publication on acceptance

- Open access: articles freely available online

- High visibility within the field

- Retaining the copyright to your article

Submit your next manuscript at $>$ springeropen.com 